\section{Dose-responses of Stem Cells from Human Exfoliated Teeth to Infrared LED Irradiation}

Ana Paula Silveira Turrioni ${ }^{1}$, Liege Aldrovandi Montoro' ${ }^{1}$ Fernanda Gonçalves Basso $^{2}$, Leopoldina de Fátima Dantas de Almeida ${ }^{3}$, Carlos Alberto de Souza Costa $^{2}$, Josimeri Hebling ${ }^{1}$

Despite several reports regarding tissue regeneration, including pulp repair induced by different light sources, only limited data have been reported concerning the effects of light-emitting diodes (LED) on stem cells from human exfoliated deciduous teeth (SHEDs). The aim of this study was to evaluate the effects of different energy densities of infrared LED on the cell viability, number of cells and mineralized tissue production by SHEDs. SHEDs were obtained from near-exfoliation primary teeth $(n=3)$, seeded in plain DMEM $\left(10^{4}\right.$ cells $/ \mathrm{cm}^{2}$ ), and irradiated by a LED prototype (LEDTable $850 \mathrm{~nm}, 40 \mathrm{~mW} / \mathrm{cm}^{2}$ ) delivering 0 (control), 2, 4, 8, 15 or $30 \mathrm{~J} / \mathrm{cm}^{2}(\mathrm{n}=9)$. Cell viability (MTT assay), cell proliferation (trypan blue assay), and mineralized nodule (MN) formation (alizarin red stain) were assessed 12 and $72 \mathrm{~h}$ post-irradiation. Data were subjected to Kruskal-Wallis and Mann-Whitney tests $(\alpha=0.05)$. Cells irradiated with 2 or $4 \mathrm{~J} / \mathrm{cm}^{2}$ exhibited higher metabolism at $72 \mathrm{~h}$, and all energy densities provided increase in cell proliferation after $12 \mathrm{~h}$. Regarding MN formation, the best results were observed at $72 \mathrm{~h}$ after SHED irradiation with 8 and 15 $\mathrm{J} / \mathrm{cm}^{2}$. It was concluded that the cell viability, cell number and MN formation by pulp cells are enhanced after exposure to infrared LED irradiation. Overall, the greatest SHED biostimulation was obtained with 4 and $8 \mathrm{~J} / \mathrm{cm}^{2}$.
'Department of Pediatric Dentistry and Orthodontics, Araraquara School of Dentistry, UNESP - Univ Estadual Paulista, Araraquara, SP, Brazil ${ }^{2}$ Department of Physiology and Pathology, Araraquara School of Dentistry, UNESP - Univ Estadual Paulista, Araraquara, SP, Brazil ${ }^{3}$ Department of Restorative Dentistry, Araraquara School of Dentistry, UNESP - Univ Estadual Paulista, Araraquara, SP, Brazil

Correspondence: Profa. Dra. Josimeri Hebling, Rua Humaitá, 1680. Centro, Caixa Postal 331, 14.801-903 Araraquara, SP, Brasil. Tel: + 55-16-3301-6334. e-mail: jhebling@foar.unesp.br

Key Words: infrared, phototherapy, pulp cells, metabolism.

\section{Introduction}

In addition to the lipopolysaccharides (LPS) released from bacteria during caries progression, the clinical procedure of caries removal may cause damage to the pulp-dentin complex. Also, some dental materials currently recommended as capping agents or liners might be cytotoxic and present poor physical or chemical properties, resulting in additional injury to the dental pulp $(1,2)$.

To reduce pulp damage or improve healing of already damaged pulp tissue, different techniques, such as phototherapy, have been assessed and recommended $(3,4)$. Low-level light therapy (LLLT), with lasers or light-emitting diodes (LED), has been widely used in dentistry for tissue and cell stimulation (5-11). Concerning the pulp tissue or pulp cells subjected to phototherapy, several authors have reported encouraging scientific data, such as increased deposition of tertiary dentin (5), enhanced cell viability and proliferation $(8,11)$, and biomodulation of inflammatory cytokines and reactive oxygen species (9). Despite these positive results, a major challenge in tissue biostimulation involving phototherapy is to define the optimal window for each cell type and desired action (3). In other words, which parameters of irradiation (energy density, wavelength, power) would be adequate for biostimulation, since it is known that cell and tissue responses may vary according to these physical parameters $(3,12)$.
In clinical situations with dentin remaining between cavity floor and pulp tissue, light needs to overcome the dentin barrier to reach and stimulate the subjacent pulp tissue. It has been demonstrated that LED irradiation (blue, red and infrared spectra) is capable of propagating through a dentin barrier up to $1.0 \mathrm{~mm}$ thick $(13,14)$. The authors reported that the smallest scattering of light occurred when infrared LED was used. Later, it was shown that the light emitted by diodes is able not only to cross the dentin barrier but also to stimulate the underlying pulp cells (11).

Despite the promising cell-biostimulatory results obtained with phototherapy, such as modulation of tissue inflammation (15) and stimulation of fibroblast cell metabolism, odontoblast-like cells, and human pulp cells $(10,11,16-18)$, information about the effects of infrared LED on the metabolism and mineralization ability of stem cells from human exfoliated deciduous teeth is scant. Therefore, the aim of this study was to evaluate the effects of 850-nm LED irradiation on cultured stem cells from human exfoliated deciduous teeth (SHEDs) at different energy densities.

\section{Material and Methods Primary Cultures of Pulp Cells}

Sound deciduous teeth $(n=3)$ close to exfoliation were obtained during patient care at the Pediatric Dentistry Clinic 
of Araraquara Dental School - UNESP, after approval by the local Ethics Committee (Protocol 63/11). The isolation and characterization of the primary pulp from exfoliated teeth cells used in this study followed a previously described protocol (10). The tests were performed when sufficient cells were obtained for application of the protocol, and 3rd passage cells were used. All experiments were performed in triplicate.

\section{Irradiation Device}

For cell irradiation, a previously described standardized device (LEDtable) containing 24 infrared diodes $(850 \mathrm{~nm})$ was used (9-11). The irradiance was fixed at $40 \mathrm{~mW} / \mathrm{cm}^{2}$, and the irradiation times were $50 \mathrm{~s}\left(2 \mathrm{~J} / \mathrm{cm}^{2}\right), 1 \mathrm{~min}$ and $40 \mathrm{~s}\left(4 \mathrm{~J} / \mathrm{cm}^{2}\right), 3 \mathrm{~min}$ and $20 \mathrm{~s}\left(8 \mathrm{~J} / \mathrm{cm}^{2}\right), 6 \mathrm{~min}$ and $15 \mathrm{~s}(15$ $\left.\mathrm{J} / \mathrm{cm}^{2}\right)$ and $12 \mathrm{~min}$ and $30 \mathrm{~s}\left(30 \mathrm{~J} / \mathrm{cm}^{2}\right)$ (9). All cells were irradiated in a dark room. According to a preliminary study, the time that the cells were kept out of the incubator, considering the different irradiation times, did not affect cell viability (data not shown).

\section{Cell Viability Assay (MTT assay)}

For cell viability (MTT assay) and cell counting (trypan blue assay), cells were seeded in 24-well plates $\left(10^{4}\right.$ cells $\left./ \mathrm{cm}^{2}\right)$ and incubated for $12 \mathrm{~h}$ in contact with DMEM containing 10\% FBS (Gibco, Grand Island, NY, USA). After this period, the medium was aspirated and replaced by DMEM containing only $0.5 \% \mathrm{FBS}$, to induce nutritional stress. After $12 \mathrm{~h}$, the cells were subjected to LED irradiation, and the tests were performed at 12 and $72 \mathrm{~h}$ post-irradiation.

Cell viability analysis was performed as described by Oliveira et al. (17). Briefly, DMEM was aspirated and replaced by $900 \mu \mathrm{L}$ of new culture medium (DMEM) plus $100 \mu \mathrm{L}$ of MTT solution $(5 \mathrm{mg} / \mathrm{mL}$ of methyl tetrazolium salt in PBS) (Sigma-Aldrich, St. Louis, MO, USA). Cells in contact with the MTT solution were incubated at $37^{\circ} \mathrm{C}$ for $4 \mathrm{~h}$. After incubation, the MTT solution was aspirated and replaced by $600 \mu \mathrm{L}$ of an acidified isopropanol solution (0.04 $\mathrm{N}$ of $\mathrm{HCl})$. Three aliquots from each sample were analyzed in 96-well plates. Cell viability was assessed in absorbance at $570 \mathrm{~nm}$ in a microplate reader (Thermo Plate, Nanshan District, Shenzhen, China).

\section{Cell Proliferation (Trypan Blue Assay)}

After LED irradiation, the medium in contact with the cells was replaced by $0.12 \%$ trypsin (Gibco) and kept in contact with the cells for $10 \mathrm{~min}$. After cell dissociation, a $50-\mu \mathrm{L}$ aliquot of this cell suspension was added to 50 $\mu \mathrm{L}$ of $0.04 \%$ trypan blue solution. The resulting solution was kept at room temperature for $2 \mathrm{~min}$. To perform the cell counts, $10 \mu \mathrm{L}$ of the solution were placed on a hemocytometer and the cells assessed in an automated cell counter (TC 10 Automed Cell Counter 145-0001; BIO-RAD, Hercules, CA, USA). Total cell and non-viable cell counts were performed, and cell proliferation was obtained by subtracting the non-viable cells from the total cells of the sample.

\section{Mineral Nodule Formation}

The evaluation of mineral nodules was performed using the alizarin red staining (19). Cells were seeded $\left(10^{4}\right.$ cells $\left./ \mathrm{cm}^{2}\right)$ and incubated for $48 \mathrm{~h}$ in basal medium, then kept in contact with an osteogenic medium containing $5 \mathrm{mM} \alpha$-glycerophosphate and $100 \mathrm{mM}$ ascorbic acid (Sigma-Aldrich) (19). Irradiation was performed at 12 or $72 \mathrm{~h}$ before the evaluation time. Specifically for this protocol, analysis of nodule formation was performed on the 14th day of culture. Cells were fixed with 70\% ethanol for $1 \mathrm{~h}$, then washed with distilled water for 5 min followed by staining with a $40 \mathrm{mM}$ solution of alizarin red (Sigma-Aldrich) for $20 \mathrm{~min}$, under shaking. After being stained, samples were washed twice with distilled water, for 5 min each. Some of the samples were evaluated by optical microscopy for qualitative analysis of mineral nodule formation and others were solubilized with $1 \mathrm{~mL}$ (10\% in PBS) of hexadecylpyridinium chloride monohydrate (Sigma-Aldrich) for quantitative analysis. After shaking and checking the homogeneity of the solutions, we transferred three $100-\mu \mathrm{L}$ aliquots of each sample to a 96-well plate. The absorbance was determined at $562 \mathrm{~nm}$ in an ELISA reader (Thermo Plate).

\section{Statistical Analysis}

For all statistical tests, absorbance values were transformed into percentages, with the control group (non-irradiated cells, period of $12 \mathrm{~h}$ ) as 100\%. Data were subjected to statistical analysis by the non-parametric Kruskal-Wallis test, complemented by the Mann-Whitney test $(p<0.05)$.

\section{Results}

Aiming a better data understanding, Figure 1 shows line graphs based on the median values, for MTT assay (A), Trypan Blue (B) and Alizarin Red (C). The statistical difference between groups, median, 25 percentile and 75 percentile values for each group can be observed on the Tables 1, 2 and 3 for cell viability, cell proliferation and $\mathrm{MN}$ formation, respectively.

\section{Cell Viability}

Cell viability data, considering energy densities and post-irradiation periods of evaluation, are shown in Table 1. Comparing the irradiated groups, an increase 
in cell viability was observed over time. However, $4 \mathrm{~J} /$ $\mathrm{cm}^{2}$ energy density was the only one to increase cell viability significantly compared with the control group
( $p<0.05$ ), by $27.4 \%$ and $27.8 \%$ for 12 and $72 \mathrm{~h}$, respectively. Other energy densities did not differ from those of the non-irradiated group ( $p>0.05$ ).

Table 1. Cell viability (\% of control) of stem cells from human exfoliated deciduous teeth (SHEDs) 12 and 72 $\mathrm{h}$ after irradiation with infrared LED $(850 \mathrm{~nm})$ delivering different energy densities

\begin{tabular}{lccc}
\hline $\begin{array}{l}\text { Energy density } \\
\left(\mathrm{J} / \mathrm{cm}^{2}\right)\end{array}$ & \multicolumn{3}{c}{ Post-irradiation period of evaluation (h) } \\
\cline { 2 - 4 } 0 (control) & $100.32(91.71-118.42) \mathrm{B}$ & Sig. & $204.52(143.87-206.47) \mathrm{B}$ \\
2 & $112.6(99.0-126.8) \mathrm{AB}$ & Sig. & $227.6(190.0-242.3) \mathrm{AB}$ \\
4 & $127.7(109.6-133.3) \mathrm{A}$ & Sig. & $231.6(223.3-242.9) \mathrm{A}$ \\
8 & $116.5(94.6-123.6) \mathrm{AB}$ & Sig. & $203.0(188.6-235.9) \mathrm{AB}$ \\
30 & $111.3(89.7-117.6) \mathrm{B}$ & Sig. & $204.8(164.2-248.3) \mathrm{AB}$ \\
\hline
\end{tabular}

Values are medians ( $25^{\text {th }}$ to $75^{\text {th }}$ percentiles), $n=9 . p$ value allows comparisons between post-irradiation periods (rows). Sig. = statistically significant difference $(\mathrm{p}<0.05)$. A Letters allow comparisons among energy doses (columns). Values identified by the same letter are not statistically different (Mann-Whitney, $p>0.05$ ).

Table 2. Cell proliferation (\% of control) of stem cells from human exfoliated deciduous teeth (SHEDs) 12 and $72 \mathrm{~h}$ after irradiation with infrared LED $(850 \mathrm{~nm})$ delivering different energy densities

\begin{tabular}{lccc}
\hline \multirow{2}{*}{$\begin{array}{l}\text { Energy density } \\
\left(\mathrm{J} / \mathrm{cm}^{2}\right)\end{array}$} & 12 & Period of evaluation $(\mathrm{h})$ \\
\cline { 2 - 4 } 0 (control) & $100.0(90.5-111.7) \mathrm{C}$ & Sig. & 72 \\
2 & $124.4(114.5-150.7) \mathrm{AB}$ & N.s. & $152.2(143.7-161.7) \mathrm{B}$ \\
4 & $150.0(144.5-154.0) \mathrm{A}$ & Sig. & $174.6(166.7-180.0) \mathrm{A}$ \\
8 & $130.0(105.9-140.4) \mathrm{B}$ & Sig. & $150.0(146.7-175.3) \mathrm{AB}$ \\
30 & $130.0(114.7-137.2) \mathrm{AB}$ & Sig. & $135.8(135.0-158.7) \mathrm{B}$ \\
\hline
\end{tabular}

Values are medians ( $25^{\text {th }}$ to $75^{\text {th }}$ percentiles), $n=9 . p$ value allows comparisons between post-irradiation periods (rows). Sig. = statistically significant difference $(p<0.05)$; N.s. = not statistically different $(p>0.05)$. Capital letters allow comparisons among energy doses (columns). Values identified by the same letter are not statistically different (Mann-Whitney, p>0.05).

Table 3 Mineralized nodule formation (\%) by stem cells from human exfoliated deciduous teeth (SHEDs) 12 and $72 \mathrm{~h}$ after irradiation with infrared LED $(850 \mathrm{~nm})$ delivering different energy densities.

\begin{tabular}{lccc}
\hline \multirow{2}{*}{$\begin{array}{l}\text { Energy density } \\
\left(\mathrm{J} / \mathrm{cm}^{2}\right)\end{array}$} & \multicolumn{3}{c}{ Period of evaluation (h) } \\
\cline { 2 - 4 } 0 (control) & $100.8(91.1-116.8) \mathrm{AB}$ & Sig. & $120.0(99.0-131.0) \mathrm{B}$ \\
2 & $111.8(97.2-116.0) \mathrm{AB}$ & $\mathrm{N} . \mathrm{s}$. & $111.8(105.5-118.7) \mathrm{B}$ \\
4 & $102.5(100.5-104.3) \mathrm{A}$ & N.s. & $118.5(98.8-125.9) \mathrm{B}$ \\
8 & $107.5(102.0-108.5) \mathrm{A}$ & Sig. & $140.0(123.5-163.3) \mathrm{A}$ \\
15 & $106.0(102.6-111.9) \mathrm{A}$ & Sig. & $141.4(134.8-236.9) \mathrm{A}$ \\
30 & $98.4(91.4-108.2) \mathrm{B}$ & Sig. & $123.1(105.0-127.1) \mathrm{B}$
\end{tabular}

Values are medians ( $25^{\text {th }}$ to $75^{\text {th }}$ percentiles), $n=9$. $^{\text {p-value }}$ Allows comparisons between post-irradiation periods (rows). Sig. = statistically significant difference $(p<0.05)$; N.s. = not statistically different $(p>0.05) . A_{\text {Letters }}$ allow comparisons among energy doses (columns). Values identified by the same letter are not statistically significantly different (Mann-Whitney, p>0.05). 


\section{Cell Proliferation (Trypan Blue)}

Analysis of viable cell-counting data (Table 2) demonstrated that, for the 12-hour period, all energy densities promoted an increase on cell proliferation, compared with the control group $(p<0.05)$, and better results for this period were obtained with $4 \mathrm{~J} / \mathrm{cm}^{2}(50 \%$ increase). After $72 \mathrm{~h}$, only the $4 \mathrm{~J} / \mathrm{cm}^{2}$ energy density showed statistically higher cell proliferation when compared with
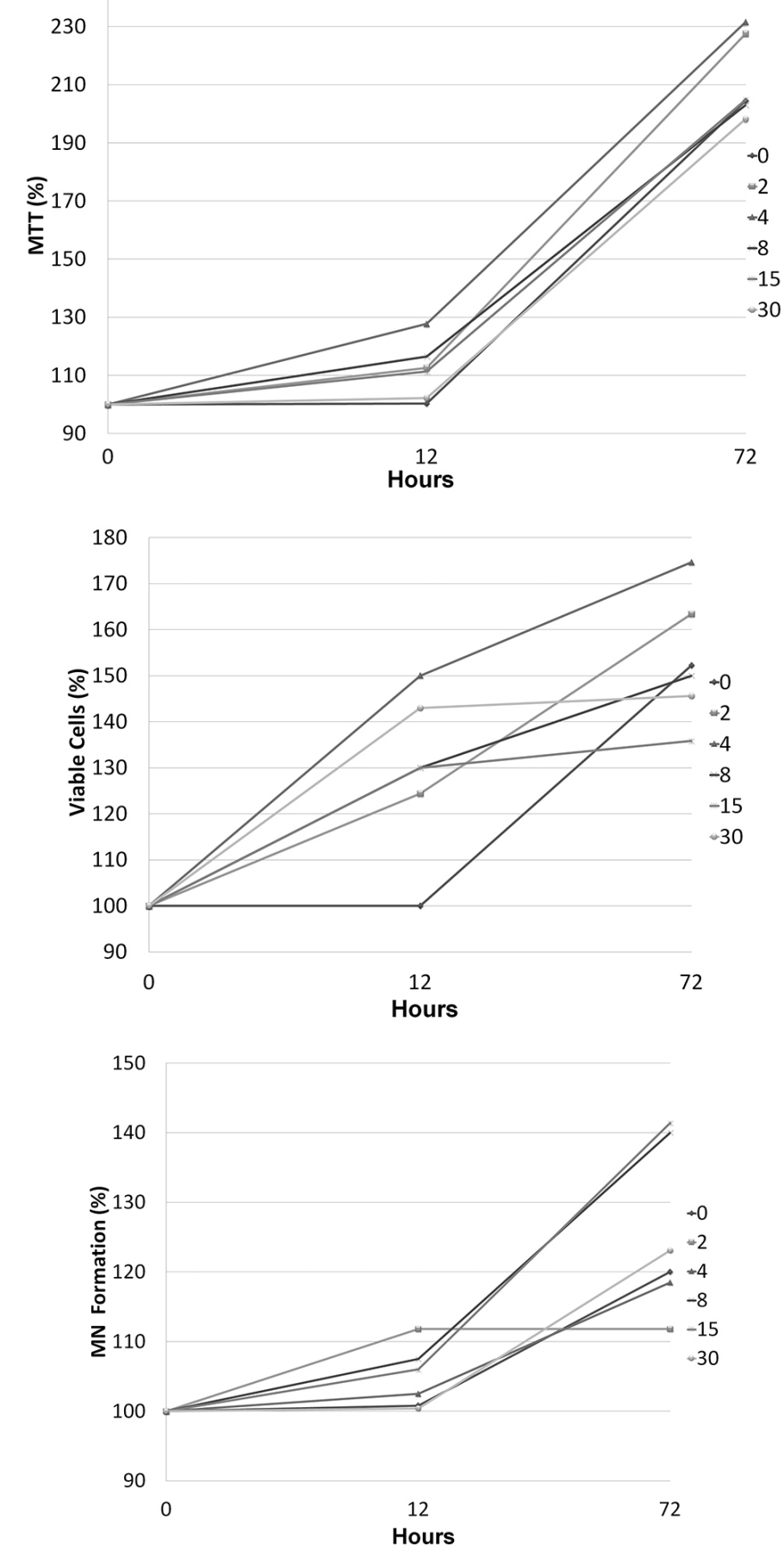

Figure 1. Line graphs based on the median values, for cell viability (A), cell proliferation (B) and mineralized nodule (MN) formation (C), 12 and $72 \mathrm{~h}$ after SHEDs irradiation with infrared LED $(850 \mathrm{~nm})$ delivering different energy densities $\left(0,2,4,8,15\right.$ and $\left.30 \mathrm{~J} / \mathrm{cm}^{2}\right)$.
A

B

the control group $(22.4 \%$ increase, $p<0.05)$. When the two evaluation periods were compared, it was observed that, for 4,8 , and $15 \mathrm{~J} / \mathrm{cm} 2$ energy densities, the period of 72 $\mathrm{h}$ was outstanding, showing higher values with statistical significance $(p<0.05)$.

\section{Mineralized Nodule Formation}

Quantitative data on mineral nodule formation by cultured pulp cells after LED irradiation are shown in Table 3. Comparison of energy densities at each period demonstrated that, for the $12 \mathrm{~h}$ period, there was no statistically significant increase in the irradiated groups when compared with the control group ( $p>0.05$ ). For the period of $72 h$, only the 8 and $15 \mathrm{~J} / \mathrm{cm}^{2}$ energy densities were able to increase mineral nodule production $(20.0 \%$ and $21.4 \%$, respectively) when compared with the control group $(p<0.05)$.

Figure 2 shows the mineral deposition by SHEDs as a function of the different energy densities and post-irradiation periods of evaluation. It was observed that the groups irradiated with 4, 8 and $15 \mathrm{~J} / \mathrm{cm}^{2}$ produced more mineralized nodules.

\section{Discussion}

The use of phototherapy for transdentinal biostimulation of pulp cells is an interesting adjuvant treatment for pulp healing during clinical procedures in operative dentistry. Based on the analysis of positive data provided by previous studies, researchers have been encouraged to develop more investigations to establish the most beneficial physical parameters of LED or laser irradiation of pulp cells $(8-11,20)$.

Current studies have assessed LED energy densities varying from $0.093 \mathrm{~J} / \mathrm{cm}^{2}$ (21) to $162 \mathrm{~J} / \mathrm{cm}^{2}(22)$ and power densities from 0.5 $\mathrm{mW} / \mathrm{cm}^{2}$ (23) to $140 \mathrm{~mW} / \mathrm{cm}^{2}$ (24). According to Alghamdi et al. (12), power values from 1 to $500 \mathrm{~mW}$ and energy densities from 0.04 to $50 \mathrm{~J} / \mathrm{cm}^{2}$ are considered low-intensity therapy parameters, recommended for the irradiation of cells in culture. Therefore, the irradiation parameters used in this study followed the recommendations of Alghamdi et al. (12) as well as those of Montoro et al. (9), who studied modulation of reactive oxygen species (ROS) and nitric oxide (NO) production by human dental pulp cells 
subjected to infrared LED therapy.

In the present study, it was shown that infrared LED irradiation can increase the viability and number of pulp cells as well as the formation of mineralized nodules, which play an important role in tertiary dentin formation (8). The energy density of $4 \mathrm{~J} / \mathrm{cm}^{2}$ up-regulated the cell viability for all evaluated periods, but the highest cell viability rate was observed at $72 \mathrm{~h}$ post-irradiation. Several studies have assessed the viability of pulp cells exposed to phototherapy $(8,11,17,18)$. Holder et al. (8) showed that viability of pulp
$12 \mathrm{~h}$

Control

$2 \mathrm{~J} / \mathrm{cm}^{2}$

$4 \mathrm{~J} / \mathrm{cm}^{2}$

$15 \mathrm{~J} / \mathrm{cm}^{2}$

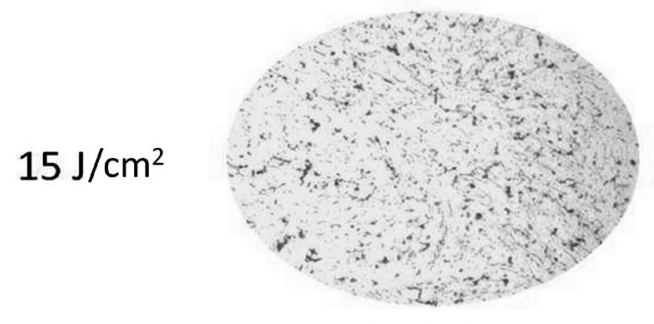

$30 \mathrm{~J} / \mathrm{cm}^{2}$
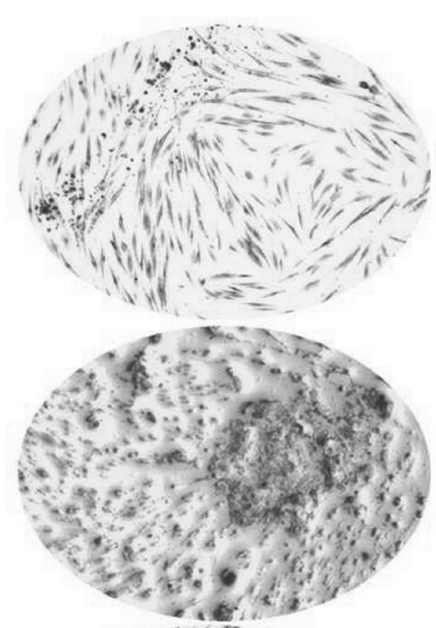

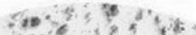

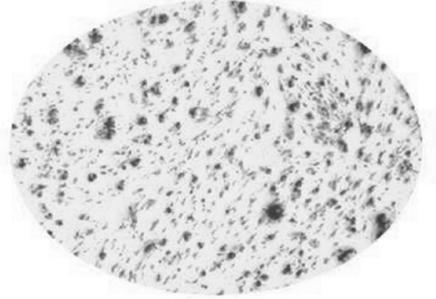

$8 \mathrm{~J} / \mathrm{cm}^{2}$

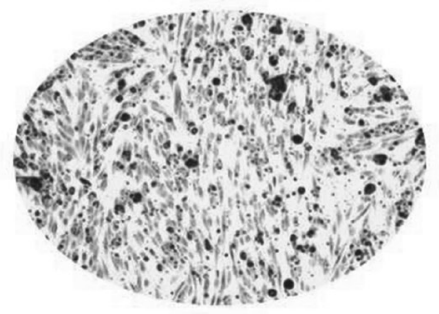

$72 \mathrm{~h}$
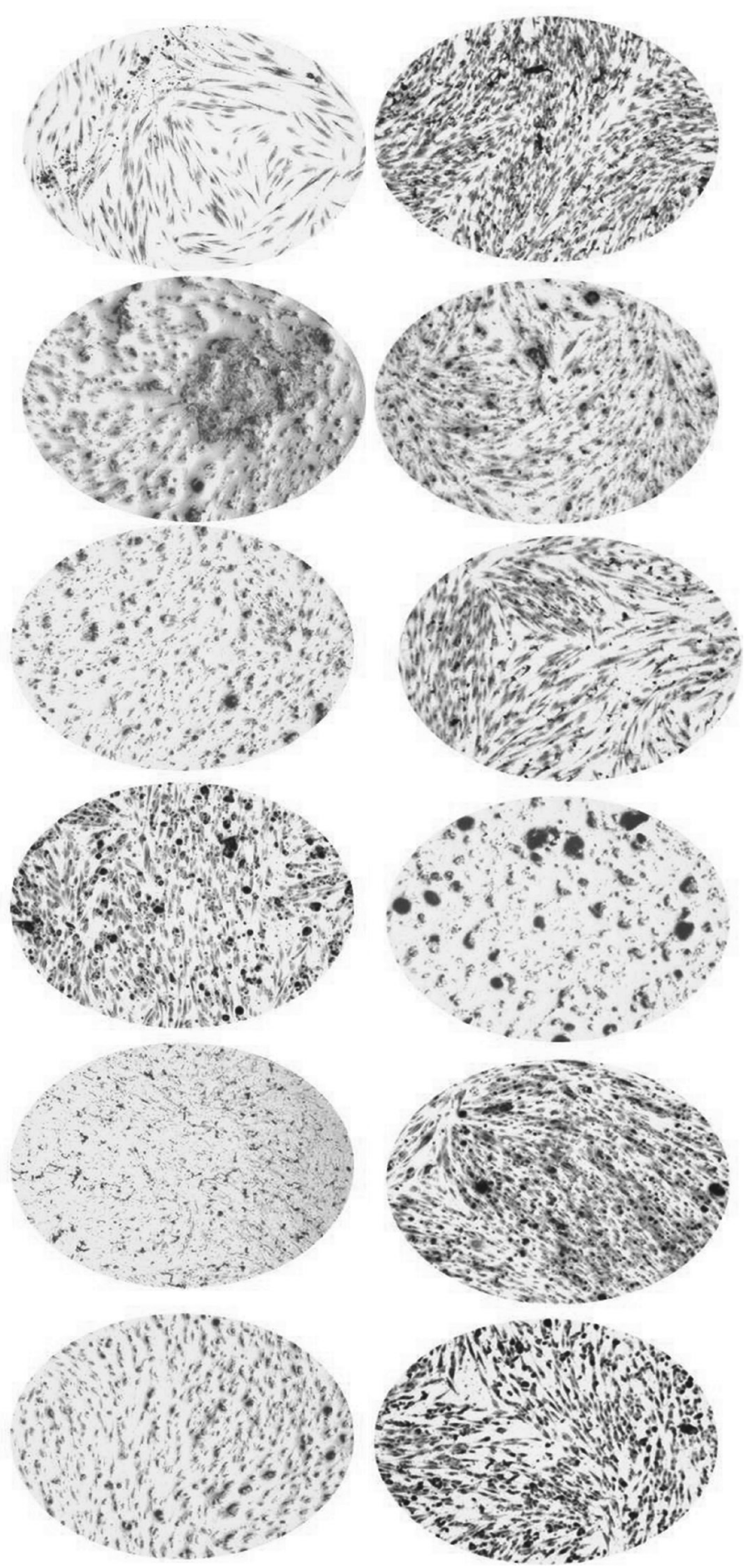

Figure 2. Panel of inverted microscope images representative of mineral deposition by SHEDs, 12 and $72 \mathrm{~h}$ after irradiation with infrared LED (850 $\mathrm{nm}$ ) delivering different energy densities $\left(0,2,4,8,15\right.$ and $\left.30 \mathrm{~J} / \mathrm{cm}^{2}\right)$. Original magnification, $4 \times$ 
cells was enhanced after exposure to one irradiation session with red LED. Transdentinal biostimulation of odontoblastlike MDPC-23 cells also occurred when the cells were subjected to three irradiation sessions (18). Possibly, a single short irradiation applied to the dentin remaining between the cavity floor and the pulp would be more appropriate for pre-restoration clinical conditions. Therefore, in the present study we decided to evaluate the responses of SHEDs exposed to a single LED irradiation. Since there is no consensus about the best irradiation parameters for pulp biostimulation, we varied only the energy densities from 2 to $30 \mathrm{~J} / \mathrm{cm}^{2}$ and assessed the cell responses at 12 and $72 \mathrm{~h}$ post-irradiation.

As determined for cell viability, the number of viable SHEDs in the present study was also enhanced after irradiation with infrared LED at the chosen parameters. The most significant increase on cell proliferation was observed at $72 \mathrm{~h}$ post-irradiation for the energy density of $4 \mathrm{~J} / \mathrm{cm} 2$. Holder et al. (8) used the BrdU method to count the number of pulp cells irradiated with LED (653 $\mathrm{nm}, 3.73 \mathrm{~mW} / \mathrm{cm}^{2}, 448 \mathrm{~mJ} / \mathrm{cm}^{2}$ ). The authors observed a higher number of cells in the irradiated groups than in control groups at 3-and 7-day post-irradiation periods. The increased cell proliferation and viability seem to be related to cytochrome c oxidase activation, which enhances levels in the respiratory chain and adenosine triphosphate (ATP), and these biochemical changes led to macroscopic effects such as increased cell proliferation (25). Analysis of these data confirms that LED therapy may increase the viability and stimulate the proliferation of pulp cells in vitro and in vivo $(10,11,20)$.

The mineral nodule formation by SHEDs was also stimulated by LED irradiation at 8 , and $15 \mathrm{~J} / \mathrm{cm}^{2}$. Analysis of these data corroborates previous studies in which mesenchymal stem cells $(21)$, odontoblast-like cells $(17,18)$ and rodent pulp cells (8) were subjected to phototherapy. In general, these cells presented increased deposition of mineralized matrix as well as enhanced expression of collagen type I, alkaline phosphatase (ALP), Runx-related transcription factor 2 (Runx2) and osteopontin, which are proteins related to the synthesis and mineralization of the collagen-rich matrix $(17,18,21)$. The molecular pathways that cause increased production of these specific proteins have not been described thus far. However, this macroeffect of phototherapy on pulp cells suggests that light can be an interesting adjuvant treatment to up-regulate the deposition and mineralization of collagen-rich dentin matrix by dental pulp cells during pulp healing. It seems that different energy doses can be the ideal parameter depending on the desired outcome. For number of cells and cell viability, $4 \mathrm{~J} / \mathrm{cm}^{2}$ showed better results. On the other hand, for MN formation, doses of 8 and $15 \mathrm{~J} / \mathrm{cm}^{2}$ stood out, suggesting that different doses should be used according with different aims.

Overall, in vitro phototherapy with infrared LED biostimulated all SHED functions assessed in the present study. Therefore, the scientific data obtained in the present study can drive future laboratory investigations or even in vivo studies in animal models to establish irradiation parameters for optimal and friendly clinical phototherapy procedures in pulp tissue regeneration.

\section{Resumo}

Apesar de diversos estudos envolvendo regeneração tecidual, incluindo o reparo pulpar induzido por diferentes fontes de luz, dados limitados têm sido reportados a respeito dos efeitos da irradiação com diodos emissores de luz (LED) sobre células-tronco de dentes decíduos esfoliados (SHEDs). 0 objetivo do presente estudo foi avaliar os efeitos de diferentes doses de energia (DE) do LED infravermelho sobre a viabilidade celular, número de células viáveis e produção de nódulos mineralizados (NM) por SHEDs. As células foram obtidas a partir de dentes decíduos próximos ao periodo de esfoliação $(n=3)$, semeadas em DMEM completo $\left(10^{4}\right.$ células/ $\mathrm{cm} 2$ ) e irradiadas utilizando um protótipo de LED (LEDTable $850 \mathrm{~nm}, 40$ $\mathrm{mW} / \mathrm{cm}^{2}$ ) com as doses de 0 (controle), 2, 4, 8, 15 ou $30 \mathrm{~J} / \mathrm{cm}^{2}$ ( $\mathrm{n=9}$ ). A viabilidade celular (MTT), o número de células viáveis (trypan blue assay) e a formação de NM (alizarin red stain) foram realizados 12 e $72 \mathrm{~h}$ após a irradiação. Os dados foram avaliados utilizando os testes Kruskal-Wallis e Mann-Whitney $(\alpha=0,05)$. As células irradiadas com 2 ou $4 \mathrm{~J} / \mathrm{cm}^{2}$ exibiram uma maior viabilidade em $72 \mathrm{~h}$, e todas as DE aumentaram o número de células viáveis após $12 \mathrm{~h}$. Para a formação de NM, os melhores resultados foram observados $72 \mathrm{~h}$ após a irradição das SHEDs, com as doses de $8 \mathrm{e}$ $15 \mathrm{~J} / \mathrm{cm}^{2}$. Concluiu-se que a viabilidade celular, o número de células e a formação de NM por células pulpares são aumentados após exposição ao LED infravermelho. De um modo geral, a melhor bioestimulação celular (SHEDs) foi obtida com 4 e $8 \mathrm{~J} / \mathrm{cm}^{2}$.

\section{Acknowledgements}

The authors acknowledge the Fundação de Amparo à Pesquisa do Estado de São Paulo - FAPESP (grants: 2011/13895-0 and 2013/17758-3) and the Conselho Nacional de Desenvolvimento Científico e Tecnológico - CNPq (grant: 301291/2010-1) for financial support.

\section{References}

1. Smith AJ, Murray PE, Sloan AJ, Matthews JB, Zhao S. Trans-dentinal stimulation of tertiary dentinogenesis. Adv Dent Res 2001;15:51-54.

2. Cohenca N, Paranjpe A, Berg J. Vital pulp therapy. Dent Clin North Am 2013;57:59-73.

3. Carroll JD, Milward MR, Cooper PR, Hadis M, Palin WM. Developments in low level light therapy (LLLT) for dentistry. Dent Mater 2014;30:465475.

4. Prindeze NJ, Moffatt LT, Shupp JW. Mechanisms of action for light therapy: a review of molecular interactions. Exp Biol Med (Maywood) 2012;237:1241-1248.

5. Tate Y, Yoshiba K, Yoshiba N, Iwaku M. Odontoblast responses to GaAIAs laser irradiation in rat molars: an experimental study using heat-shock protein-25 immunohistochemistry. Eur J Oral Sci 2006;114:50-57.

6. Lizarelli RFZ, Miguel FAC, Villa GEP, Filho EC, Pelino JEP, Bagnato VS. Clinical effects of low-intensity laser vs light-emitting diode therapy on dentin hypersensitivity. J Oral Laser Appli 2007;7:1-8.

7. Sacono NT, Costa CA, Bagnato VS, Abreu-e-Lima FC. Light-emitting diode therapy in chemotherapy-induced mucositis. Lasers Surg Med 2008;40:625-633.

8. Holder MJ, Milward MR, Palin WM, Hadis MA, Cooper PR. Effects of red light-emitting diode irradiation on dental pulp cells. J Dent Res 
2012;91:961-966.

9. Montoro LA, Turrioni APS, Basso FG, de Souza Costa CA, Hebling J. Infrared irradiation photobiomodulation of oxidative stress in human dental pulp cells. Int Endod J 2013;47:747-755.

10. Turrioni AP, Basso FG, Montoro LA, Almeida L de F, Costa CA, Hebling J. Phototherapy up-regulates dentin matrix proteins expression and synthesis by stem cells from human exfoliated deciduous teeth. J Dent 2014;42:1292-1299.

11. Turrioni AP, Basso FG, Alonso JR, Oliveira CF, Hebling J, Bagnato VS, Souza Costa CA. Transdentinal cell photobiomodulation using different wavelengths. Oper Dent 2015;40:102-111.

12. Alghamdi KM, Kumar A, Moussa NA. Low-level laser therapy: a useful technique for enhancing the proliferation of various cultured cells. Lasers Med Sci 2012;27:237-249.

13. Turrioni AP, Oliveira CF, Basso FG, Moriyama LT, Kurachi C, Hebling J, et al.. Correlation between light transmission and permeability of human dentin. Lasers Med Sci 2012;27:191-196.

14. Turrioni AP, Alonso JRL, Basso FG, Moriyama LT, Hebling J, Bagnato VS, et al.. LED light attenuation through human dentin: a first step toward pulp photobiomodulation after cavity preparation. Am J Dent 2013;26:319-323.

15. Ablon G. Combination 830-nm and 633-nm light-emitting diode phototherapy shows promise in the treatment of recalcitrant psoriasis: preliminary findings. Photomed Laser Surg 2010;28:141-146.

16. Vinck EM, Cagnie BJ, Cornelissen MJ, Declercq HA, Cambier DC. Increased fibroblast proliferation induced by light emitting diode and low power laser irradiation. Lasers Med Sci 2003;18:95-99.

17. Oliveira CF, Basso FG, Lins EC, Kurachi C, Hebling J, Bagnato VS, et al.. In vitro effect of low-level laser on odontoblast-like cells. Laser Phys
Lett 2011:8:155-163.

18. Oliveira CF, Basso FG, Reis RI, Parreiras-e-Silva LT, Lins EC, Kurachi C, et al.. In vitro transdentinal effect of low-level laser therapy. Laser Phys 2013;23:1-6.

19. Min JH, Ko SY, Cho YB, Ryu CJ, Jang YJ. Dentinogenic potential of human adult dental pulp cells during the extended primary culture. Human Cell 2011;24:43-50.

20. Ferreira ANS, Silveira S, Genovese WJ, Cavalcante Araújo V, Frigo L, Mesquita RA, et al.. Effect of GaAIAs laser on reactional dentinogenesis induction in human teeth. Photomed Laser Surg 2006;24:358-365.

21. Kim HK, Kim JH, Abbas AA, Kim DO, Park SJ, Chung JY, et al.. Red light of $647 \mathrm{~nm}$ enhances osteogenic differentiation in mesenchymal stem cells. Lasers Med Sci 2009;24:214-222.

22. Taoufik K, Mavrogonatou E, Eliades T, Papagiannoulis L, Eliades G, Kletsas D. Effect of blue light on the proliferation of human gingival fibroblasts. Dent Mater 2008;24:895-900.

23. Vinck EM, Cagnie BJ, Cornelissen MJ, Declercq HA, Cambier DC. Green light emitting diode irradiation enhances fibroblast growth impaired by high glucose level. Photomed Laser Surg 2005;23:167-171.

24. Gritsch K, Ponsonnet L, Schembri C, Farge P, Pourreyron L, Grosgogea B. Biological behaviour of buccal cells exposed to blue light. Mater Sci Eng C 2008;28:805-810.

25. Gao X, Xing D. Molecular mechanisms of cell proliferation induced by low power laser irradiation. J Biomed Sci 2009;16:4.

Received March 20, 2015 Accepted May 13, 2015 